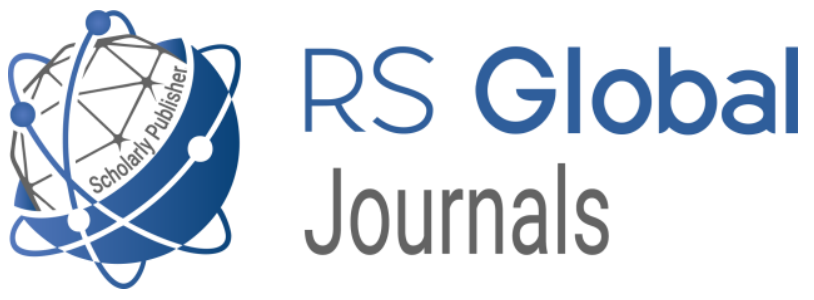

Scholarly Publisher

RS Global Sp. z O.O.

ISNI: 0000000484952390

Dolna 17, Warsaw, Poland 00-773

Tel: +48226022703

Email: editorial_office@rsglobal.pl

JOURNAL International Journal of Innovative Technologies in Social Science

p-ISSN

$2544-9338$

e-ISSN

2544-9435

PUBLISHER

RS Global Sp. z O.O., Poland

ARTICLE TITLE

РАЗЛИЧНЫЙ АСПЕКТ (Рамзан Кадыров, Джохар Дудаев, Царь Грузии Георгий VII, Ибрагим I Ширваншах)

$\operatorname{AUTHOR}(\mathbf{S})$

Генри Купрашвили

Kuprashvili Henri. (2021) Different Aspect (Ramzan Kadyrov, Dzhokhar Dudayev, King George VII of Georgia, Ibrahim I of ARTICLE INFO Shirvan). International Journal of Innovative Technologies in Social Science. 3(31). doi: 10.31435/rsglobal_ijitss/30092021/7673

DOI https://doi.org/10.31435/rsglobal_ijitss/30092021/7673

RECEIVED

26 July 2021

ACCEPTED

03 September 2021

PUBLISHED

07 September 2021

LICENSE

This work is licensed under a Creative Commons Attribution

4.0 International License.

(C) The author(s) 2021. This publication is an open access article. 


\title{
РАЗЛИЧНЫЙ АСПЕКТ (Рамзан Кадыров, Джохар Дудаев, Царь Грузии Георгий VII, Ибрагим I Ширваншах)
}

\author{
Генри Купрашвили, Доктор политических наук, профессор факультета права и \\ международных отношений Грузинского технического университета, Грузия, \\ ORCID ID: https://orcid.org/0000-0002-7013-1407
}

\section{DOI: https://doi.org/10.31435/rsglobal_ijitss/30092021/7673}

\section{ARTICLE INFO}

Received 26 July 2021

Accepted 03 September 2021

Published 07 September 2021

\section{KEYWORDS}

Ramzan Kadyrov, Chechnya, National interests, Gene Pool, Politics.

\begin{abstract}
At this stage of Chechen history, a politician appeared in the political arena who saved the history of the Chechen gene pool. I think personally that, willynilly or not, Ramzan Kadyrov had a chance to play a clearly positive role in the critical period of modern Chechen history, which, undoubtedly, will be objectively evaluated by history in a prosperous future. In this regard, the subject of discussion may be only one, consciously or unwittingly, he accepted such a choice. I am sure that unwittingly.
\end{abstract}

Citation: Kuprashvili Henri. (2021) Different Aspect (Ramzan Kadyrov, Dzhokhar Dudayev, King George VII of Georgia, Ibrahim I of Shirvan). International Journal of Innovative Technologies in Social Science. 3(31). doi: 10.31435/rsglobal_ijitss/30092021/7673

Copyright: (C) 2021 Kuprashvili Henri. This is an open-access article distributed under the terms of the Creative Commons Attribution License (CC BY). The use, distribution or reproduction in other forums is permitted, provided the original author(s) or licensor are credited and that the original publication in this journal is cited, in accordance with accepted academic practice. No use, distribution or reproduction is permitted which does not comply with these terms.

Введение. Известно, что в любой стране общество (население), свидетель происходящих в ней глобальных политических процессов, воспринимает их субъективно (в большей степени от того, насколько эти процессы личностным образом были с ним в соприкосновении...), следовательно, их оценки, в основном далеки от истины. И ничего удивительного в этом, ведь оценки политических процессов 100\%-ми не являются и тогда, когда выводы делаются на основании научных анализов и осмысления тенденций в целом, что под силу лишь специалистам этой области (в качестве исключения и некоторым личностям). Ясно, что реформы осуществляются за счет современного общества, они непосредственно своими бытовыми проблемами соприкасаются с ними, главным образом не «со сбором урожая», а с трудностями, являющимися спутником черной работы «до сбора урожая». К тому же, они, за исключением единиц, испытывают дефицит реальной, полноценной информации (доступ закрыт для них), а та, что имеют, перекроена замаскированными субъективными, идеологическими сообщениями, политическими интригами и сведениями, исходящими из личных соображений в условиях борьбы за любую власть. Несмотря на это, именно эта категория людей (неосведомленных в политике) имеют наибольшие претензии, что они та и разбираются в политике, и твердо убеждены в верности собственных суждений и выводов. А в это время, политическая реальность весьма сложна и различна от их наивных и субъективных представлений.

Результаты исследования. Часто, долгосрочные государственные интересы требуют от власти, которой вверена судьба государства и народа, принятие неприемлемых и непонятных для народа решений, предпринимать непопулярные шаги. Известны слова Шарля де Голля (Charles de Gaulle; 1890-1970): «В политике предают либо собственную страну, либо избирателей, я выбираю второе». Трудно не согласиться. Избиратель противоречив, разношерстен, в нем преобладает «урапатриотизм», чаще всего его действия определяются эмоциональным зарядом... дистанцированы от стратегических государственных интересов, в основном ориентированы на удовлетворение 
временных, секундных, субъективных потребностей, а государство, верховная и вечная ценность... поскольку совмещение обеих данностей не представляется возможным, ясно, что управляющий страной не имеет права предавать государственные интересы, идя на поводу воле избирателей (разумеется, здесь подразумевается личность с масштабом государственного мышления, а не случайно пришедший к власти временщик).

Поэтому, в преобладающих случаях, по прошествии определенного времени (1-3 поколения), будущие поколения обнаруживают, что политик (реформа), непринятый современниками, оказывается «работал» на перспективу и принес много пользы народу (будущим поколениям) и государству, либо же наоборот.

Политические процессы современной истории Чечни, в некотором аспекте напомнили мне о Грузии, времен набегов Тамерлана (Timur; 1336-1405), последствием которых стало истребление грузинского генофонда и начало заката грузинской государственности, результаты которых по сей день пожинает Грузия. В тот сложнейший период для Грузии неизмеримо огромное значение имело то, какого типа правитель был во главе государства. Политик, выделяющийся мужеством и храбростью, который для защиты отечества был готов до последней капли крови, без компромиссов, оглядки назад, не задумываясь сразиться с врагом, или политик, подмявший под себя эмоции (как бы сложно это не было), оценивший соотношение сил, международную политическую ситуацию, взвесивший существующие и ожидаемые опасности и противопоставивший врагу разумную политику во имя наименьших потерь для покоренной страны и народа. В те времена власть в Грузии принадлежала политикам первого типа, повелевая судьбой государства.

Нам известно, что прославившийся храбростью, героически чеченский народ вот уже 300 - 400 лет ради завоевания свободы и независимости неустанно сражается с пришлым врагом. Фактом является одно, Россия все же завоевала их территорию, однако поработить народ ей не удалось, и не сумела поставить их на колени. Россия пошла даже на то, что переселила народ с собственных земель в Центральную Азию, но и это не подавило духовную силу чеченцев. С этой точки зрения, по достоинству уникальный народ, заслуживающий мое глубочайшее уважение.

Процесс крушения Советского Союза, разрушение величайшей империи, российская политическая элита встретила неподготовленной, что особенно чувствовалось в эпоху правления президента Бориса Ельцина (Boris Yeltsin; 1931-2007). В то время, бывшие Советские Республики воспользовались моментом и начался парад провозглашения независимостей. Чеченский лидер тех времен, Джохар Дудаев (Dzhokhar Dudayev; 1944-1996) так же попытался, подключить Чечню в те процессы и на волне происходящих процессов освободиться от России, исполнив заветную чеченскую мечту провозглашения независимой Чеченской Республики.

Началась русско-чеченская война. Однако, в одинокой и неравной во всех отношениях борьбе против величайшей империи потерпела поражение эта идея завоевания независимости. В то время в мире не существовала выгодная для Чечни международная политическая среда. Так называемая цивилизованная политическая элита, влиятельные демократические государства либерального запада, выставляющие себя «поборниками справедливости и прав», не подали руку помощи этому несправедливо угнетенному героическому народу, не защитив их права, бросив его одиноко против разъяренной величайшей российской империи. Ясно, здесь необходимо принять во внимание то обстоятельство, что международная обстановка, баланс сил политических интересов, происходящие в мире политические процессы, являются решающими в подобных случаях. Много примеров того, что многомиллионные народы самоотверженно на протяжении многих лет сражаются за независимость, не добившись цели. А в это время, в совершенно другой ситуации, некоторым малочисленным народам вовсе и не пришлось сражаться, и совершенно неожиданно для себя же, получают независимость.

Русско-чеченская война привела к величайшим жертвам. Погиб так же и Джсхар Дудаев. И что важно, фиаско потерпела тогда и сама идея Джохара - воспользоваться моментом и вместе с другими добиться независимости так же и Чечне.

В этой ситуации чеченский народ встал перед исторически стратегическим выбором, необходимо было выбрать одно из двух:

Первое. Продолжать привычную для нее мужественную, невообразимо неравную и не компромиссную борьбу за независимость. Несмотря на то, что одиноко стоит напротив 
разъяренной огромной империи, хорошо ведая и то, что никому нет дела до нее в силу сложившейся для Чечни во всех отношениях невыгодной международной политической ситуации, и к тому же, прекрасно осознавая то, что обречена на погибель перед беспощадным врагом. Но чеченское героическое прошлое, генетика и мужественный дух не позволяет отступать назад и героически погибает под этим воинственным духом, ибо смыслом жизни кавказца «лучше достойная смерть, чем бесславная жизнь», как это воспел еще в 12 веке Шота Руставели (Shota Rustaveli; 1172-1216).

Второе. Проявить политическую мудрость, хорошо продумавши не только о сегодняшнем, но и завтрашнем дне народа, будущем, вечном сосуществовании с международным сообществом, т. е. о временном отступлении во имя спасения будущего народа, как бы это ни было сложным для ее мужественного менталитета. Для того, чтобы временно дать себе передышку для спасения основного генофонда народа, собраться сил и подготовиться для подходящего момента.

Разумеется, каждый из этих выборов имеет своих сторонников и противников. Полагаю, что для Чечни на сегодня именно второй путь является верным, как залог спасения народа (вечной ценности). По моему мнению, идея достижения независимости Чечни могла еще до прихода к власти Владимира Путина (Vladimir Putin; œ. 1952) иметь перспективу, однако после вступления его на должность президента, вовсе исключено. Если бы бескомпромиссная политика Джохара вновь продолжилась, ясно, что в этой неравной, длительной войне против вооруженного современной военной техникой и информационными технологиями агрессора чеченский генофонд мог вовсе истребиться. Ясно и то, что Владимир Путин не остановился бы ни перед чем, пытающийся поставить на ноги парализованную Ельцинскую Россию и вернуть ей былую славу бескомпромиссно, любой ценой. А посему выбор первого варианта означало бы, поставить перед катастрофой и без того малочисленный чеченский народ, генофонд этого уникального народа.

В такой обстановке мое внимание среди современных политических деятелей привлекла политика Рамзана Кадырова (Ramzan Kadyrov; В. 1976) и его стратегические результаты в истории чеченского народа. Рассуждая об этой политике для политологов, отправной точкой должен стать национальный интерес Чечни и выводы делать не на основании оценки его отдельных поступков, а на основании анализа тенденций выраженных в конечных результатах этих поступков, увиденных в целом. В процессе обсуждений об исторических лицах и политических процессах необходимо не гадание, а соответственное мышление логики фактов.

Российские и западные политические интересы определяются политическими целями задачами, стоящими перед ними на сегодняшний день. О Р. Кадырове и Чечне все вооружены собственными твердыми позициями. Одно можно выделить, Р. Кадыров представлен одиозной фигурой, он в сегодняшнем политическом пространстве обладает отрицательным имиджем, и представляют его некой чудовищной личностью и даже страшилкой. Я владею информацией о нем исключительно из средств массовой информации, не знаком с ним лично, и не обязательно. Однако в разрезе истории современной Чечни анализ результатов его деятельности дает мне возможность увидеть этого современного политика в совершенно ином ракурсе. Рамзану Кадырову выпала особая миссия в долгосрочной политической истории Чечни. Именно в момент созданной безвыходной политической ситуации в Чечне появился он на политической арене. Его деятельность - это олицетворение вышеупомянутого второго варианта.

Наверняка слышали поговорку о том, что «если нарвешься ненароком на медведя, будь с ним ласковым». Вот и он ласков с Путиным и временно удалось уберечь чеченцев от неминуемой катастрофы, и поставил точку в процессе полного истребления чеченского генофонда. В результате мудрой восточной политики ласки и временных уступок успокоилась военная обстановка. Спасшийся народ начал лечить раны, восстановление сил. Уверен, что это временная пауза не искоренит в чеченцах стремление к свободолюбию и независимости, ибо с наступлением подходящего момента вновь будет готов к борьбе, как с оружием в руках, так и мирными формами во имя достижения заветной независимости. Повторяю, если бы продолжилась политика непримиримой борьбы Джохара, чеченский генофонд мог бы совершенно истребиться.

Тут, как я уже отметил выше, хочу провести параллель с периодом Тамерлана в грузинской истории. К тому времени, страна едва оправилась от недавних ран и только вступала на путь возрождения. Восстановление Грузии в пределах прежних государственных границ и возвращение его высокого международного авторитета после свержения татаро- 
монгольского ига в первой половине XIV века (что в один голос отмечается европейскими и восточными историческими источниками) был результатом укрепления грузинской внутренней экономической и политической сфер [2, с. 663]. Однако, после внезапного появления Тамерлана, словно налетевшего урагана, государство оказалось перед огромной опасностью. В этой ситуации решающее значение имела способность власти оперативного прояснения политической обстановки, оценки соотношения сил и выбора метода борьбы, гарантирующего спасение государства с наименьшими разрушениями и жертвами.

Грузинские цари, отец и сын, Баграт V и Георгий VII (который вступил на престол после Баграта), с моей точки зрения, не оказались в конкретный исторический момент политически достаточно подготовленными к управлению страной. Они вовсе исключили дипломатические способы и выбрали бескомпромиссное военное противостояние с врагом, что, в конечном счете, завершилось катастрофическим поражением Грузии. Между прочим, в то время, в отличие от них, хорошо разобравшись в политической ситуации и четко выработав политическую платформу, встретил появление Тамерлана правитель Ширвана (территория нынешнего Азербайджана) Ширван шах Шейх Ибрагим Дербент (Ibrahim I of Shirvan; 1382-1418). Он встретил покорно с богатыми дарами жестокого покорителя и спас государство от разрушения (Ширван оказался в регионе единственным государством, которого не коснулись набеги Тамерлана). А после смерти Темура, восстановил, и независимость Ширвана, и расширил границы государства [1].

Проявление мужества и храбрости - дело чести, когда речь идет о личной судьбе, однако правителю, которому вверено государство и судьбы собственного народа, следует проявлять куда больше мудрости, он просто не вправе рисковать ими, ставя их на весы судьбы. Самоотверженный борец за независимость родины, прославившийся мужеством и храбростью Георгий VII, вместо применения мудрой политики и дипломатии, бесстрашно и бескомпромиссно встретил войска Тамерлана. На мой взгляд, тяжелейшей и неисправимой ошибкой была та бессмысленно мужественная и резкая политика, которую он вел в отношении Тамерлана. Это дало повод кровожадному Тамерлану, еще не раз опустошить и разрушить страну, «и он уничтожил население Грузии десятками тысяч и превратил все в пепел и прах, куда только вступил ногу свою» [2, с. 674], вражеские войска угнали с собой много пленных [4].

Союзничество с Тамерланом, пусть даже на вассала- подданнических условиях, было вполне возможным и уберегло бы от множества бед... Так поступили Теимураз ${ }^{1}$ и Ерекле, ${ }^{2}$ когда признали себя вассалами Надир Шаха, ${ }^{3}$ Ерекле был с походом в Индии, прогнали и Турков с Грузии, а затем, после наступления подходящего момента, прогнали и Надир Шаха... В конечном счете, этого кровожадного тирана Грузия удивительно ловко использовала для достижения собственных целей... Приблизительно тоже самое сделал и Георгий Блистательный ${ }^{4}$ в свое время.

Георгий VII не сумел проявить политическую мудрость, и позволил временному событию, тому временному обрушившемуся урагану, ${ }^{5}$ что имело имя - Тамерлан (чья собранная империя развалилась одновременно с его кончиной), мгновенно истребить творческий и здоровый народ большой и единой Грузии, его самую активную, боеспособную и воинственную часть. И совсем недавно, освобожденная Георгием V Блистательным (George V of Georgia; 1286-1346) от монголов и поднявшаяся на ноги, объединенная и возродившаяся страна в невероятно короткий период целиком рухнула.

Это оказалось настолько невосполнимой потерей, настал период такого падения государства, что Грузия по сей день не смогла оправиться. Итогом было именно это, и теперь, оправдание этого мужеством и храбростью царя, дескать, спас государство от принятия мусульманской веры, не видится мне вполне правильным. Разве не можно было справиться с нависшей опасностью через 9 лет, применив разумную политику, оттянув время, как того добились Георгий V Блистательный или Деметре II Самоотверженный (который ценой собственной жизни

\footnotetext{
${ }^{1}$ Теимураз II (Teimuraz II of Kakheti; 1700-1762) царь Кахетии и Картли.

${ }^{2}$ Ерекле II (Heraclius II of Georgia; 1720-1798) Картлийский и кахетинский царь.

${ }^{3}$ Надир шах (Nader Shah; 1688-1747) - иранский шах.

${ }^{4}$ Георгий V Блистательный (George V of Georgia; 1286-1346) - грузинский царь.

5 Как ведет себя человек, когда внезапно обрушивается ураган? Мужественно преградит путь ему, погубив себя, или переждет до прояснения погоды, ведь ураган, как внезапно обрушивается, так же неожиданно и исчезает.
} 
спас собственное население)? Нужно было проявление самой маленькой дипломатии, а не бессмысленного мужества и резкости, что в первую очередь создавала угрозу судьбе страны и жизням собственного населения, и лишь в самой меньшей степени самого царя. Этого правителя Бог наградил больше мужеством и отвагой, чем дальновидностью и дипломатичностью, свойственной политику. А в тот момент стране больше всего нужен был именно мудрый политик.

Для Грузии настало еще одно, не менее роковое, политическое обстоятельство. Для Грузии роковым оказалось не только то, что набеги Тамерлана унесли жизни стольких тысяч людей, обескровив тело государства и превратив в опустошенную пустыню его процветающие земли, а серьезной, еще большей угрозой оказалось то, что севернее Грузии, за кавказским хребтом произошли огромные изменения. Родственные Грузии северокавказские народы до того момента государственно ассоциировали себя с Грузией, и как культурно, так и по вере, их страна принадлежала сфере влияния Грузии. «Тамерлан организовал тщательный поход на те северокавказские страны и народы, которые проживали на северных склонах кавказских гор и имели связь с Грузией. Тамерлан разгромил их христианские культовые памятники и принудил принять ислам. После походов Тамерлана северокавказские племена оказались оторванными от Грузии, более того, вступили в противостояние с ней. Вместе с другими факторами, и этот, в последующих веках способствовали падения могущества Грузии» [3].

Выводы. Так что на этом этапе чеченской истории на политической арене появился политик, спасший истории чеченский генофонд. Считаю лично, что волей или неволей, Рамзану Кадырову довелось сыграть явно положительную роль в критический промежуток современной чеченской истории, что, несомненно, в благополучном будущем будет объективно оценено историей. В этой связи предметом обсуждения может быть только одно, осмысленно или невольно он принял такой выбор. Я уверен, что не осмысленно.

\section{ЛИТЕРАТУРА}

1. Очерки истории Грузии в 8 томах, т. 3, (редакторы тома 3. Анчабадзе и В. Гучуа), издательство „Советская Грузия““, Тбилиси, 1979.

2. Петрушевский И. И. Великий патриот ширваншах Ибрагим. Баку, 1942, с. 26.

3. Отечественная война, длиной 17 лет. Манглийский митрополит Анания (Джапаридзе). 2015 г. 26 декабря. http://meufeanania.info/samamulo/ последняя проверка 01.09.2018.

4. Налбандян В. Тбилиси в старо армянской письменности, с древних времен до конца XVIII века. Тбилиси, 1959, с. 113. 